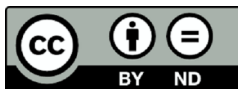

Acta Poloniae Historica

112,2015

PL ISSN 0001-6892

Rafat Rutkowski

Institute of History, Polish Academy of Sciences

\title{
THE PLATONIC CONCEPT OF THE MEMORY OF ANCIENT DEEDS IN THE CHRONICLES OF MASTER VINCENTIUS KADŁUBEK AND THEODORICUS MONACHUS
}

\begin{abstract}
The article discusses the reception of the Platonic concept of memory of ancient deeds in twelfth-century historical writing in the 'younger Europe'. It focuses on the myth of Atlantis, as described in the translation of Timaeus by Calcidius, illustrating the manner in which two twelfth-century chroniclers - Master Vincentius Kadłubek and Theodoricus Monachus - used the said myth as a structural basis for their accounts of the past of Poland and Norway, respectively. Both chroniclers invoke Plato's idea of a memory of ancient past that survives through centuries without recourse to scripture and is the province not of the people whose history it concerns, but rather of one that is closely related, or, at times - of an older generation.
\end{abstract}

Key words: Plato's Timaeus, William of Conches, Master Vincentius Kadłubek, Theodoricus Monachus, medieval historiography, memory, Icelanders

My interest is in the medieval appropriations of certain ideas put forward in Timaeus by Plato, the philosopher's only work known in the West during that period thanks to a partial Latin translation with commentaries, composed by Calcidius in the fourth century. The translation, which had a significant impact on medieval philosophy, survives today in roughly seventy five handwritten copies, mostly produced in the eleventh or twelfth century. Though at least two copies reached Cracow during the fifteenth century, Polish scholars educated abroad cited the work even earlier; such was the case with Vitelon and, as shall become clear, Kadłubek. ${ }^{1}$

${ }^{1}$ Cracow, BJ 529 II, fol. 4v-83v (scan available online at <http://pka.bj.uj.edu. pl/var/eScrypt/Rkp_BJ_529_II/html/pol/start-calosc.htm> [Accessed: June 10, 
One of the subjects addressed in Timaeus is the myth of Atlantis. Through the mouth of Critias, Plato recounts the naval victory of the Athenians - an ideal society - over the powerful Atlanteans. Yet, the triumph was followed by a terrible flood that obliterated nearly all of humanity and consigned the memory of the glorious events to near oblivion. Its survival was achieved through the efforts of a narrow group of people who transmitted the story orally from one generation to another. The myth of Atlantis thus constitutes a highly intriguing form of reflection on historical memory and its dependence on scripture and orality. Since it is precisely the appropriation of the Platonic idea of the memory of ancient deeds that is my subject here, medieval philosophical or theological treatises will only be of limited interest to me. Instead, I will consider the works of two chroniclers described as sole representatives of twelfth-century Renaissance in Norway and Poland. ${ }^{2}$ The works in question are the Historia de antiquitate regum Norwagiensium by Theodoricus Monachus, written in ca. 1177-88, and the Chronica Polonorum by Master Vincentius Kadłubek, completed within some two decades of the former. ${ }^{3}$

2015]); BJ 665, fol. 1r-76r [non vidi]. For a description of the codices, see Maria Kowalczyk (ed.), Catalogus codicum manuscriptorum medii aevi latinorum in Bibliotheca Jagellonica Cracoviae asservantur, iii (Wrocław, 1984), 264-6; iv (Wrocław, 1988), $436-8$.

${ }^{2}$ On this subject, see Aleksander Gieysztor, 'Ośrodki i peryferie kultury umysłowej w Europie XII wieku', Studia Źródtoznawcze, xx (1976), 10-18; Marian Plezia, 'Kronika Kadłubka na tle renesansu XII wieku', in idem, Scripta minora. Łacina średniowieczna $i$ Wincenty Kadtubek (Kraków, 2001), 229-42; Sverre Bagge, 'Theodoricus Monachus: Clerical Historiography in Twelfth-Century Norway', Scandinavian Journal of History, xiv, 2 (1989), 133; Lars B. Mortensen, 'Det 12. århundredes renæssanse i Norge: Teoderik Munk og Romerriget', in Øivind Andersen and Asbjørn Aarseth (eds.), Antikken i norsk litteratur (Bergen, 1993), 17-35.

${ }^{3}$ On Theodoricus, see Gustav Storm, 'Indledning', in Monumenta Historica Norvegiae. Latinske kildeskrifter til Norges historie i middelalderen udgivne efter offentlig foranstaltning (Kristiania, 1880), i-xiv; Arne O. Johnsen, Om Theodoricus og hans Historia de antiquitate regum Norwagiensium (Oslo, 1939); Jens S. Th. Hanssen, 'Observations on Theodoricus Monachus and his History of the Old Norwegian Kings, from the End of the XII. sec.', Symbolae Osloenses, xxix (1945), 164-80; idem, 'Theodoricus Monachus and European Literature', Symbolae Osloenses, xxvii (1949), 70-127; Gudrun Lange, Die Anfünge der isländisch-norwegischen Geschichtsschreibung (Reykjavík, 1989); Bagge, 'Theodoricus Monachus: Clerical Historiography', 113-33; and idem, 'Theodoricus Monachus: The Kingdom of Norway and the History of Salvation', in Ildar H. Garipzanov (ed.), Historical Narratives and Christian Identity on 
Both chroniclers likely shared the experience of studying in France. ${ }^{4}$ Apparently, it was there that they became acquainted with Timaeus, the source for their views on the memory of ancient deeds. That Theodoricus had used the Platonic treatise has been an established fact for years. The Norwegian chronicler explicitly cites Plato when discussing natural disasters that decimate mankind every fifteen thousand years. This was noted already over a century ago, with the translation by Calcidius mentioned as a direct source, perhaps mediated through Macrobius or Hugo of Saint Victor. The matter was treated as a piece of erudite trivia, with little heed given to the significance it could have had for a broader interpretation of the chronicler's work. As research into the question had in any case been abandoned a long time ago, the question seems all the more enticing today. ${ }^{5}$ The case of Kadłubek may seem a polar opposite, since no direct reference to Plato is found in his work. This put historians in a quandary over the source of the original dialogic form of the first three books of the work by the Bishop of Cracow, with Cicero and Macrobius considered as sources of inspiration. ${ }^{6}$ Only recently have numerous borrowings from

a European Periphery (Leiden and Boston, 2011), 71-90; Peter Foote, 'Introduction', in Theodoricus Monachus, An Account of the Ancient History of the Norwegian Kings, trans. David McDougall and Ian McDougall (London, 1998), vii-xxxi. The Norwegian classical philologist Egil Kraggerud has been working on a new edition of the chronicle since "the latter part of the nineties": < http://egil.kraggerud. no> [Accessed: Oct. 21, 2013]. For a review of literature on Kadłubek, see Karol Kollinger, 'Vincentiana. Materiały do bibliografii', in Andrzej Dąbrówka and Witold Wojtowicz (eds.), Onus Athlanteum. Studia nad Kronika biskupa Wincentego (Warszawa, 2009), 476-527; and Wojciech Drelicharz, Idea zjednoczenia królestwa $w$ średniowiecznym dziejopisarstwie polskim (Kraków, 2012), 70-91.

${ }^{4}$ For a summary of debates on the scholarly background of both chroniclers, see Lars B. Mortensen, 'The Anchin manuscript of Passio Olavi (Douai 295), William of Jumièges, and Theodoricus Monachus: New evidence for intellectual relations between Norway and France in the 12th century', Symbolae Osloenses, lxxv, 1 (2000), 165-89; and Zenon Kałuża, Lektury filozoficzne Wincentego Kadtubka. Zbiór studiów (Warszawa, 2014).

${ }^{5}$ For a discussion of the problem, see Tenney Frank, 'Some Classical Quotations from the Middle Ages', Classical Philology, iv, 1 (1909), 83; Fredrik Paasche, 'Über Rom und das Nachleben der Antike im norwegischen und isländischen Schrifttum des Hochmittelalters', Symbolae Osloenses, xiii (1934), 136-8; Johnsen, Om Theodoricus, 32, 56.

${ }^{6}$ For a discussion of the genesis of the dialogic form of the chronicle, see Oswald Balzer, 'Studyum o Kadłubku', in idem, Pisma pośmiertne, ii (Lwów, 1935), 
Calcidius been found in the chronicle, and the problem continues to attract the attention of Polish medievalists. ${ }^{7}$

The stylistic and temporal correspondence between the works by Theodoricus and Vincentius, as well as the fact that both were

90-6; Brygida Kürbisówna, 'Motywy makrobiańskie w Kronice mistrza Wincentego a szkoła Chartres', Studia Źródtoznawcze, xvii (1972), 70 ff.; Kazimierz Liman, 'Topika w Kronice polskiej Wincentego Kadłubka', Studia Źródłoznawcze, xx (1976), 97 ff.; Marian Plezia, 'Dialog w kronice Kadłubka', in idem, Scripta minora, 217-27; Teresa Michałowska, Średniowiecze (Warszawa, 2006), $134 \mathrm{ff}$.

${ }^{7}$ Traces of a reading of Timaeus in Kadłubek were first incontrovertibly identified by Jerzy Mańkowski, 'Krak, uczeń Sokratesa (Glosa do Kadłubka Chronica Polonorum I 5, 3)', in Alina Nowicka-Jeżowa and Paweł Stępień (eds.), Inspiracje platonskie literatury staropolskiej. Materiaty $z$ konferencji zorganizowanej przez Zespót Badań Literackich nad Historia Kultury Epok Dawnych Instytutu Literatury Polskiej Uniwersytetu Warszawskiego 14-15 października 1998 r. (Warszawa, 2000), 147-50. Primacy may also be claimed by Marek Cetwiński, who preceded Mańkowski by a year when claiming that Kadłubek's main source "was ... probably Plato's Timaeus with commentary by Calcidius; ... the Bishop of Cracow likely adapted the dialogic form from Plato”, idem, 'Kadłubek i Pitagoras. Recepcja filozofii Zachodu w polskich kronikach średniowiecznych', in Selim Chazbijewicz and Józef Kwapiszewski (eds.), Tradycje duchowe Europy Środkowej $i$ Wschodniej (Słupsk, 1999), 126 (reprinted in idem, Metamorfozy ślaskie. Studia źródtoznawcze i historiograficzne [Częstochowa, 2002], 65 ff.). The Platonic origin of Kadłubek's deployment of the scene of a feast as the setting for a discussion of ancient deeds was incidentally clear already to Jan of Dąbrówka (15th c.), a fact indicated by his reference to Timaeus for an explanation of the convivium philosophicum; see Ioannes de Dąbrówka, Commentum in Chronicam Polonorum Magistri Vincenti dicti Kadtubek, ed. Marian Zwiercan (Monumenta Poloniae Historica [hereinafter: MPH], N.S., xiv, Kraków, 2008), lib. iv, 191; cf. Marian Zwiercan, Komentarz Jana z Dąbrówki do Kroniki Mistrza Wincentego zwanego Kadtubkiem (Wrocław, 1969), 149, 151, 155; Andrzej Dąbrówka, Średniowiecze. Korzenie (Warszawa, 2005), 108, 407. The problem noted by Mańkowski was explored in: Zenon Kałuża, 'Kadłubka historia mówiona i historia pisana (Kronika I 1-2 i II 1-2)', Przeglad Tomistyczny, xii (2006), 61-120; Zenon Kałuża and Dragos Calma, 'O filozoficznych lekturach Mistrza Wincentego', in Dąbrówka and Wojtowicz (eds.), Onus Athlanteum, 231-78; iidem, 'Wokół Wilhelma z Conches i Bernarda z Clairvaux. O trudnych do ustalenia związkach Kroniki wincentyńskiej z pisarstwem XII-wiecznym', Cistercium Mater Nostra, ii, 2 (2008), 75-97; Witold Wojtowicz, 'Memoria i uczta. Kilka uwag o założeniach ideowych kroniki Mistrza Wincentego', in Dąbrówka and Wojtowicz (eds.), Onus Athlanteum, 337-47; idem, 'Ateny i pamięć. Kilka uwag o założeniach ideowych Kroniki Mistrza Wincentego', in Łukasz Grützmacher (ed.), Narracja - Historia - Fikcja. Dawne kultury w historiografii $i$ w literaturze (Warszawa, 2009), 87-99; Kałuża, Lektury filozoficzne, passim; Jacek Banaszkiewicz, 'Master Vincent and His Way to Revive and Present the Oldest History of the Lechites-Poles', forthcoming 
interested primarily in the myth of Atlantis, invite a closer look at the ways in which the ideas it served to propagate were appropriated for the authors' own purposes. The notion of comparing the two chronicles seems particularly appealing as a means of proving that - all differences notwithstanding - both authors derived their ideas on memory from texts belonging to the same philosophical tradition. My purpose is, indeed, to prove that the Norwegian chronicler knew the twelfth-century Glosae super Platonem by William of Conches, and maybe even the aforementioned translation by Calcidius itself. As far as Vincentius is concerned, it has been ascertained that Calcidius, and not William, was his inspiration. ${ }^{8}$ Whatever the immediate sources, I believe that both chronicles share the same idea which I, following Calcidius, call praecipua memoria vetustatis. ${ }^{9}$ It is a memory of ancient deeds characterised, firstly, by persistence through centuries without recourse to scripture, and secondly, by being the domain not of the people whose past it concerns, but a closely related other or members of a previous generation. In this context, ignorance of one's own history becomes a discrediting feature.

(I hereby thank the author for sharing this article prior to its publication, as well as for the encouragement to write this text and numerous discussions about its contents).

${ }^{8}$ As has recently been proven, Kadłubek used a codex which included the translation by Calcidius, his letter to Osius, and Accessus ad Platonem by William of Conches. However, he was unfamiliar with the latter's glosses. See Kałuża, Lektury filozoficzne, 285-301.

${ }^{9}$ The possibility was suggested already by Banaszkiewicz, 'Master Vincent'. For earlier attempts at comparing Kadłubek's work with medieval Scandinavian historiography, see Stella M. Szacherska, 'Mistrz Wincenty a Saxo Gramatyk', Studia Źródłoznawcze, xx (1976), 46-55; Lars B. Mortensen, 'Philosophical Learning on the Edges of Latin Christendom: Some Late Twelfth-Century Examples from Scandinavia, Poland, and Palestine', in Sten Ebbesen and Russell L. Friedman (eds.), Medieval Analyses in Language and Cognition. Acts of the symposium The Copenhagen School of Medieval Phiolosophy January 10-13, 1996 organized by The Royal Danish Academy of Sciences and Letters and The Institute for Greek and Latin, University of Copenhagen (København, 1999), 301-13; idem, 'Introduction', in Inger Ekrem and Lars B. Mortensen (eds.), Historia Norwegie (København, 2003), 26. 
The myth of Atlantis, which Hermocrates describes as "ex historia uetere narratio", was unknown to Athenians. ${ }^{10}$ Ancient deeds were consigned to oblivion by the passing of time as well as the demise of the persons involved. ${ }^{11}$ How, then, could knowledge of those deeds survive until the times of Critias the Younger, who told of them to his three companions at the feast? In fact, Critias heard the tale as a young boy from his grandfather, Critias the Elder, who heard it from Solon, who, in turn, heard it from an Egyptian priest of the goddess Neith. Thus, we are dealing with a sequence of four generations striving to preserve the memory of the tale. ${ }^{12}$ Let us turn to the final link in that chain, which originates with a trip to Egypt by the creator of Athenian democracy. Here, we learn of the city of Sais, whose people worshipped the goddess Neith (an analogue of Athena) and exhibited particular cordiality toward Athenians on account of bonds of kinship. ${ }^{13}$ In the words of the source:

And Solon said that when he travelled there he was held in great esteem amongst them; moreover, when he was questioning such of their priests as were most versed in ancient lore about their early history, he discovered that neither he himself nor any other Greek knew anything at all, one might say, about such matters. And on one occasion, when he wished to draw them on to discourse on ancient history, he attempted to tell them the most ancient of our traditions, concerning Phoroneus and Niobe; and he went on to tell the legend about Deucalion and Pyrrha after the Flood, and to give the geneology of their descendants; and by recounting the number of years occupied by the events mentioned he tried to calculate the periods of time. Whereupon one of the priests said, "O Solon, Solon, you Greeks are always

${ }^{10}$ Timaeus a Calcidio translatus commentarioque instructus, ed. Jan H. Waszink (London and Leiden, 1975), 20d, p. 12. (In absence of Waszink's edition, I quote after <http://clt.brepolis.net/llta/Default.aspx > [Accessed: March 5, 2015]. The numbering of the chapters follows <http://12koerbe.de/pan/timaios.htm $>$ [Accessed: March 5, 2015].)

${ }^{11}$ Timaeus a Calcidio, 21a, p. 12: "res gestas huius urbis memorabiles diuturnitate interituque hominum annullatas euanuisse, inter quas unam prae ceteris illustrem"; 21d, p. 13: "De maximo, inquit, eximiae uirtutis et famosissimo titulo quem gessit haec ciuitas, cuius extincta memoria est tam morte eorum qui gesserunt quam impendio temporis."

${ }^{12}$ For details and comments, see Eric Voegelin, 'Plato's Egyptian Myth', The Journal of Politics, ix, 3 (1947), $312 \mathrm{ff}$.

${ }^{13}$ Timaeus a Calcidio, 21e, p. 13. 
children: there is not such a thing as an old Greek." And on hearing this he asked, "What mean you by this saying?" And the priest replied, "For therein you possess not a single belief that is ancient and derived from old tradition, nor yet one science that is hoary with age." 14

\section{Then, the priest explained that Greeks had not forgotten their own history without a reason. ${ }^{15}$ Indeed,}

And this is the cause thereof: There have been and there will be many and diverse destructions of mankind, of which the greatest are by fire and water, and lesser ones by countless other means. For in truth the story that is told in your country as well as ours, how once upon a time Phaethon, son of Helios, yoked his father's chariot, and, because he was unable to drive it along the course taken by his father, burnt up all that was upon the earth and himself perished by a thunderbolt - that story, as it is told, has the fashion of a legend, but the truth of it lies in the occurrence of a shifting of the bodies in the heavens which move round the earth, and a destruction of the things on the earth by fierce fire, which recurs at long intervals. At such times all they that dwell on the mountains and in high and dry places suffer destruction more than those who dwell near to rivers or the sea. ${ }^{16}$

${ }^{14}$ Ibidem, 22a-22b, pp. 13 ff.: "Quo Solo profectum se satis hospitaliter honoratum esse referebat expertumque liquido, quod de uetustatis memoria nullus nostrae nationis uir ne tenuem quidem habeat scientiam. Denique cum in conuentu sacerdotum, penes quos praecipua sit memoria uetustatis, eliciendi studio quae scirent uerba faceret de antiquissimis historiis Athenarum, Phoroneo et Nioba, postque inundationem mundi de Pyrrha et Deucalione, studioseque prosequi pergeret prosapiam renouatae gentis humanae usque ad memoriam parentum annorumque numerum recenseret, inrisum se esse a quodam ex sacerdotibus qui diceret: O Solo, Graeci pueri semper estis nec quisquam e Graecia senex. Cur istud diceret percontatum Solonem. Quia rudi nouellaque estis memoria semper nec est, inquit, ulla penes uos cana scientia”. In my view, whether Solon really travelled to Egypt or not has no bearing on the interpretation of the story of the trip - on this matter, see Voegelin, 'Plato's Egyptian Myth', 316; John G. Griffiths, 'Atlantis and Egypt', Historia. Zeitschrift für Alte Geschichte, xxxiv, 1 (1985), 3-28; Luc Brisson, Plato the Myth Maker, trans. Gerard Naddaf (Chicago and London, 1998), 26 ff., Kathleen A. Morgan, 'Designer History: Plato's Atlantis Story and Fourth-Century Ideology', The Journal of Hellenic Studies, cxviii (1998), 109 ff.

15 Timaeus a Calcidio, 22b, p. 14: "Nec immerito".

${ }^{16}$ Ibidem, 22b-22d, p. 14: “... multae quippe neces hominum partim conflagratione partim inundationibus uastantibus acciderunt. Denique illa etiam fama, quae uobis quoque comperta est, Phaethontem quondam, Solis filium, affectantem officium patris currus ascendisse luciferos nec servatis sollemnibus 
However, due to particularly advantageous natural conditions, the inhabitants of Egypt were immune to the effects of such catastrophes. ${ }^{17}$ Thus, remembrances of the past (both their own and of others) took the shape of inscriptions inside the temples. Not so in Greece, where newly rebuilt structures were repeatedly destroyed. As the priest explained to Solon, "and so you have to begin all over again like children, and know nothing of what happened in ancient times, either among us or among yourselves." 18

The account quoted above includes several interesting details. Firstly, it states that the tale of the political system of ancient Athens and the expedition against Atlantis persisted from generation to generation without recourse to scripture. Even though the Egyptian priest cites inscriptions inside the temple, he did not read them directly to Solon, but rather recounted the story orally, having committed it to memory. ${ }^{19}$ According to Critias the Elder, when Solon brought the story to Greece, he refrained from setting it in writing, choosing instead to maintain the oral tradition..$^{20}$ Over the following centuries, the tradition of the ancient history of Athens remained with the house of Critias. ${ }^{21}$ This mode of transmission of the story reflects Plato's views on the near-inexhaustible capacity of human memory. For the

aurigationis orbitis exussisse terrena ipsumque flammis caelestibus conflagrasse, fabulosa quidem putatur, sed est uera. Fit enim longo interuallo mundi circumactionis exorbitatio, quam inflammationis uastitas consequatur necesse est. Tunc igitur hi qui in siccis et editis locis mansitant magis pereunt quam uicini litoribus et fluuiis." For a discussion with comments, see Brisson, Plato the Myth Maker, $110 \mathrm{ff}$.

${ }^{17}$ Timaeus a Calcidio, 22d-22e, p. 14.

${ }^{18}$ Ibidem, 22e-23b, pp. 14 ff.: "Qua ratione fit, ut neque uestras proprias res antiquas nec aliorum sciatis eaque ipsa, quae recensere memoriter arbitrabare non multum distant a puerilibus fabulis". On the 'childishness' of Solon's tale, see Daniel A. Dombrowski, 'Atlantis and Plato's Philosophy', Apeiron. A Journal for Ancient Philosophy and Science, xv, 2 (1981), 121ff.; Morgan, 'Designer History', 103; Brisson, Plato the Myth Maker, $22 \mathrm{ff}$. Luc Brisson notes the absence of chronology in Solon's tale and its presence in the story of the Egyptian priest.

${ }^{19}$ As noted by Brisson, Plato the Myth Maker, p. 25-39.

${ }^{20}$ Timaeus a Calcidio, 21d, p. 13. For a discussion with commentary, see Morgan, 'Designer History', 108-14.

${ }^{21}$ The likelihood of this mode of transmission is maintained in: Eberhard Zangger, 'Plato's Atlantis Account: A Distorted Recollection of the Trojan War', Oxford Journal of Archaeology, xii, 1 (1993), 79; and Brisson, Plato the Myth Maker, 17 ff., 25-31. 
Ancient philosopher, not only is scripture unnecessary for remembering, but it also leads to the death of mnemonic ability. ${ }^{22}$

Another point of interest is the correspondence of knowledge of ancient deeds with old age, and of ignorance with childhood. ${ }^{23}$ Already Critias the Younger notes that his grandfather told him the tale as he neared his ninetieth birthday. ${ }^{24}$ In the words of the Egyptian priest, on the other hand, Greeks were children bereft of memory, and their genealogies resembled childish fables. Thirdly, according to his account, the Greeks had forgotten their history due to natural disasters. ${ }^{25}$ Meanwhile, ancient past remained forgotten in part due to the passing of time, but also due to the death of those who had committed deeds of bygone glory. The past that seemed forever lost turned out to have only been waiting for the one who would bring it back from oblivion.

\section{III}

Let us therefore consider how Master Vincentius uses the aforementioned text by Calcidius. As I already noted, the chronicler never admits to having read Timaeus ${ }^{26}$. However, he cites the work both in style (hidden quotes) and in structural and conceptual elements (dialogic form, the concept of memory).

Already in his opening sentences, Kadłubek ascertains that the virtue of the ancient res publica owed its lustre "not to writings of the parchment, but to deeds of glorious valour." The dignity of hereditary dukes, on the other hand, "seemingly shrouded in oblivion, still

22 On Plato's views on memory, see Walter J. Ong, Orality and Literacy: The Technologizing of the Word (2nd edn., London and New York, 2002), 78-81 and passim. Ong rightly notes that Plato puts his diatribe against scripture in the mouth of Socrates and sets it in writing (here, the reference is to Phaedrus). Brisson, Plato the Myth Maker, 37 ff.; Janet Coleman, Ancient and Medieval Memories: Studies in the Reconstruction of the Past (Cambridge, 1995), 5-14; Paul Ricoeur, La mémoire, l'histoire, l'oubli (Paris, 2000) (I have used the Polish edition: Pamięć, historia, zapomnienie, trans. Janusz Margański [Kraków, 2006], 18-27).

${ }^{23}$ For a discussion with comments, see Voegelin, 'Plato's Egyptian Myth', 312 ff.; Brisson, Plato the Myth Maker, 56; Morgan, 'Designer History', 103.

${ }^{24}$ Timaeus a Calcidio, 21a-21c, p. 12: "Narrabat ergo grandis natu, ut qui ad nonagesimum iam propinquaret annum, me tunc agente annos decem."

${ }^{25}$ For a discussion with comments, see Brisson, Plato the Myth Maker, 34.

${ }^{26}$ As noted by Kałuża, Lektury filozoficzne, 290. 
glows with a curious radiance, which couldn't be extinguished by the tempests of time." 27 Virtue (virtus), an idea central to Kadłubek's account, is thus inextricably bound with memory, and, somewhat by definition, resistant to oblivion. ${ }^{28}$ Its presence in the ancient history of Poland can only be traced through "felicior ... recordatio" - for the purpose of which the narrator recounts a dispute between two earnest, venerable personages, Jan (John) and Mateusz (Matthew), which provides the axis for the first three books of the chronicle. Their discourse concerns "the order, progress, and fulfilment of the res publica" and is witnessed by Vincentius himself, who attends to the two eminences during a feast (convivium) as a rationalis and takes up the account of Polish history on his own when the dignitaries have departed. ${ }^{29}$

The narrator of the chronicle testifies to the complete veracity of the recordatio of Jan and Mateusz by describing them as "ambo

${ }^{27}$ Magistri Vincentii dicti Kadtubek Chronica Polonorum, ed. Marian Plezia (MPH, N.S., 11, Kraków, 1994; hereinafter: Vincent, Chronica), I, 1: 1-2, p. 6: "Fuit, fuit quondam in hac re publica uirtus! quam uelut quedam celi luminaria, non scripture quidem membranulis, set clarissimis gestorum radiis patres conscripti illustrauere. Non enim plebei aborigines, non uendicarie illi principate sunt potestates, set principes succedanei. Quorum serenitas licet nube ignorantie obducta uideatur, mira tamen rutilantia rutilat, que tot seculorum tempestatibus extingui non potuit."

${ }^{28}$ On the concept of memory in Vincentius, see Banaszkiewicz, 'Master Vincent'; Wojtowicz, 'Memoria i uczta', 339f f.; idem, 'Ateny i pamięć', 87 ff. However, I am not entirely convinced by the theoretical underpinnings of Witold Wojtowicz's analyses, bound as they are with liturgical memory. More on the concept of virtus in: Marek Cetwiński, 'Identitas est mater societatis. Kadłubek o zawiązkach kultury i społeczeństwa', in Antoni Barciak (ed.), Źródta kultury umysłowej w Europie Środkowej ze szczególnym uwzględnieniem Górnego Ślaska (Katowice, 2005), 15-21; Paweł Żmudzki, 'De huius rei publice origine - The Making of a Medieval Nation', forthcoming (my deepest thanks to the author for sharing the article before its publication).

${ }^{29}$ Vincent, Chronica, I, 1: 2-3, p. 6: "de huius rei publice origine, progressu et consummatione"; ibidem, III, 31 - IV, 1, pp. 128-30. On the narrative framing of the chronicle, see Brygida Kürbisówna, 'Jak mistrz Wincenty pojmował historię Polski', Studia Źródtoznawcze, xx (1976), 65; eadem, 'Wstęp', in Mistrz Wincenty Kadłubek, Kronika Polska (Wrocław and Warszawa, 2003), LX ff.; Plezia, 'Dialog w kronice Kadłubka', 226 ff.; Edward Skibiński, 'Dialog w Kronice Mistrza Wincentego', Symbolae Philologorum Posnaniensium Graecae et Latinae, vii (1988), 129-41; Wojtowicz, 'Memoria i uczta', 344-7; idem, 'Ateny i pamięć', 96-9; Banaszkiewicz, 'Master Vincent'. 
grandeui", and furthermore "sententiis graues". The characters themselves, though, saw themselves as children for lacking access to a necessary 'arcane knowledge'. The bishops therefore play the role of figures of authority as well as the infantile Athenians bereft of knowledge of their own history. ${ }^{30}$ Seeking to gain the deepest possible insight into the past and identify the reason for "nostrarum constitutionum infantiam", an apparent purpose of the aforementioned cana scientia, one of them - Mateusz - recounts the tale of a certain elder ("grandis natu quidam"). ${ }^{31}$ In a similar vein, Bildad in the Book of Job instructed

For inquire, please, of bygone ages, and consider what the fathers have searched out. For we are but of yesterday and know nothing, for our days on earth are a shadow. ${ }^{32}$

${ }^{30}$ Addressing Mateusz, Jan observes: "Nos enim hodierni sumus, nec ulla hesternitatis est in nobis cana scientia" (Vincent, Chronica, I, 1, 3, 6; a paraphrase of the words of the Egyptian priest - Timaeus a Calcidio, cap. 22b, 14). Jan responds: "Scis quia in antiquis est sapientia et in multo tempore prudentia, me uero in hac parte infantulum fateor, ut etiam utrum huius instantis simplex aliqua precesserit portiuncula, prorsus non nouerim. Quod tamen perueridica maiorum narratione condidici, non silebo" (I, 2: 1, p. 6). The contradictions in the depiction of the debaters were noted by Kałuża, Lektury filozoficzne, 102 ff., 106-9, 111 ff. Cf. also the remarks of Bronisław Geremek, 'Wyobraźnia czasowa polskiego dziejopisarstwa średniowiecznego', Studia Źródtoznawcze, xxii (1977), 13 ff.; Mańkowski, 'Krak, uczeń Sokratesa', 149; Banaszkiewicz, 'Master Vincent'.

${ }^{31}$ A quote from: Timaeus a Calcidio, 21a, p. 12. On the elder in question, see Jacek Banaszkiewicz, Polskie dzieje bajeczne Mistrza Wincentego Kadtubka (Wrocław, 2002), 235 ff.; Mańkowski, 'Krak, uczeń Sokratesa', 149; Grzegorz Myśliwski, " "Pamiętnicy". Ludzie sędziwi jako źródła wiedzy o przeszłości na ziemiach polskich (do końca XVI w.)', in Roman Michałowski (ed.), Europa barbarica, Europa christiana. Studia mediaevalia Carolo Modzelewski dedicata (Warszawa, 2008), 115; Kałuża, Lektury filozoficzne, $102 \mathrm{ff}$., $109 \mathrm{ff}$.

32 Michaele Tvvedale (ed.), Biblia Sacra juxta Vulgatam Clementinam. Editio electronica (London, 2005), 504ff: "Interroga generationem pristinam et dilligenter investiga patrum memoriam (hesterni quippe sumus, et ignoramus, quoniam sicut umbra dies nostri sunt super terram)". The analogy was noted by Katarzyna Chmielewska, Rola wątków i motywów antycznych w "Kronice polskiej" Mistrza Wincentego zwanego Kadtubkiem (Częstochowa, 2003), 33, n. 89. As Zenon Kałuża perceptively notes, "the concept is identical [to that in Kadłubek], but the terms of the opposition bear different names, as Kadłubek's hodierni correspond to Job's hesterni, and Kadłubek's hesterni bear the names of patres or generatio pristina in Job" (idem, Lektury filozoficzne, 101 ff., n. 3). 
Let us return to the chronicle. The tale of Mateusz's elder concerned the combativeness of ancient Poles, who, untrammelled by any territorial boundaries, subdued and subjugated not only neighbouring lands, but also the Danish isles ("Danomarchicas insulas"), taking King Cnut prisoner. ${ }^{33}$ As has been known for some time, the story was modelled on the tale of the conquest of Atlantis. ${ }^{34}$

Somehow, the elder disappears from view further into Vincentius's account of Polish history. Apparently, the character - an obvious replica of Plato's Critias the Elder - was no longer of use to Kadłubek. Thus, we are dealing with what Jacek Banaszkiewicz describes as a "three-generational probing of ancient history for information, which grants us a look into matters consigned to oblivion." 35 Contrary to the past conviction of scholars, this is a purely ideological gesture which, rather than invoking actual events, simply follows a literary model in the shape of Timaeus. ${ }^{36}$ The quartet of Critias the Younger, Critias the Elder, Solon, and the Egyptian priest, 'engaged' by Calcidius, corresponds to Kadłubek's triad: the chronicler, the bishops, and the elder. ${ }^{37}$

In general, however, the memory of ancient Polish history remained resistant to "tot seculorum tempestates", and only "nube ignorantie obducta uideatur". ${ }^{38}$ The task of the bishop of Cracow was thus to

${ }^{33}$ Vincent, Chronica, I, 2: 2-6, p. $6 \mathrm{ff}$.

${ }^{34}$ Noted by Kałuża, Lektury filozoficzne, $109 \mathrm{ff} ., 114 \mathrm{ff}$.

${ }^{35}$ Incidentally, Banaszkiewicz does not yet note the Platonic sources of this 'probe': Banaszkiewicz, Polskie dzieje bajeczne, 236. See also: idem, 'Master Vincent'; Kałuża, Lektury filozoficzne, $101 \mathrm{ff}$., $108 \mathrm{ff}$.

${ }^{36}$ As rightly noted by Plezia, 'Dialog w kronice Kadłubka', 217-8, and Kałuża, Lektury filozoficzne, 34-8, 117. Some believed that Matthew, the bishop of Cracow, was Kadłubek's main source, and perhaps even the real author of the first three books of the chronicle, see Joachim Lelewel, Uwagi nad Mateuszem herbu Cholewa polskim XII. wieku dziejopisem a w szczególności nad piérwsza dzieiów jego xięga (Warszawa and Wilno, 1811), 23-42; Janusz Bieniak, 'Jak Wincenty rozumiał i przedstawiał ustrój państwa polskiego', in Dąbrówka and Wojtowicz (eds.), Onus Athlanteum, 43; Eduard Mühle, 'Einleitung', in Die Chronik der Polen des Magister Vincentius (Darmstadt, 2014), 19. As Gerard Labuda observed, though, for reasons of chronology alone, the chronicler could not have listened to a debate between the two eminences; see idem, Studia nad poczatkami państwa polskiego, ii (Poznań, 1988), 25-6.

${ }^{37}$ On the pattern, see Kałuża, Lektury filozoficzne, $108 \mathrm{ff}$.; Banaszkiewicz, 'Master Vincent'.

${ }^{38}$ Vincent, Chronica, I, 1: 1, p. 6. 
"ueras patrum effigies de sinu obliuionis ... excidere". ${ }^{39}$ That the goal was fully attainable is clear. As it turns out, Polish history knew no "unconditional" forgetting that would lead to an irreversible loss of memory about the past. Its excavation was made possible not through books, but by the venerable knowledge of elders. ${ }^{40}$

\section{IV}

Let us now consider the quotation from Plato in the Historia de antiquitate regum Norwagiensium. In chapter eighteen, devoted to Saint Olaf's march from Rus to Norway, Theodoricus observes that the men who accompanied the future martyr were far larger and physically stronger than the writer's contemporaries. This view agreed with the belief that men tended to diminish in size and strength in time, a trend philosophers were unlikely to miss, knowing "that earlier there had been a flood and that the present world would end in a conflagration." ${ }^{41}$ Here, the chronicler quotes from Lucan's Bellum civile

${ }^{39}$ Ibidem, 'Prologus', 2: 2, p. 4. For a discussion with commentaries, see Juliusz Domański, 'Prolog Kroniki polskiej Mistrza Wincentego zwanego Kadłubkiem. Próba enarracji', Przeglad Tomistyczny, xii (2006), 35; Witold Wojtowicz, 'Niektóre aspekty retoryczne Prologu Kroniki Mistrza Wincentego', in Elżbieta Dąbrowicz (ed.), Teatr wymowy. Formy i przemiany retoryki użytkowej (Białystok, 2004), 47-52; idem, 'Memoria i uczta', 341, 346; idem, 'Ateny i pamięć', passim; Banaszkiewicz, 'Master Vincent'.

${ }^{40}$ The famous letter of Athalaric, on the other hand, discusses how Cassiodorus "reges Gothorum longa oblivione celatos latibulo vetustatis eduxit". Historian "lectione discens" thus collected "quod per librorum campos passim fuerat ante dispersum", as these matters "vix maiorum notitia cana retinebat" (M.A. Cassiodori senatoris Variarvm libri dvodecim, ed. Theodor Mommsen [MGH AA, 12, Berlin, 1894], IX, ep. 25, $291 \mathrm{ff}$.). The situation of Cassiodorus was thus both similar to and different from that of Kadłubek. Though both "pulled ancient history from the mouth of oblivion", the former used books in his ventures, while the latter depended on the knowledge of the elder. Conversely, the Roman states that ancient history did not survive in the memory of elders, while the Pole notes that it was not committed to parchment. On the letter, see Walter Goffart, 'Jordanes's Getica and Disputed Authenticity of Gothic Origins from Scandinavia', Speculum, lxxx (2005), 381 ff.; Robert Kasperski, Teodoryk Wielki i Kasjodor. Studia nad tworzeniem "tradycji dynastycznej Amalów" (Kraków, 2013), 31-4.

${ }^{41}$ Theodrici Monachi Historia de antiquitate regum Norwagiensium, ed. Gustav Storm (Monumenta Historica Norvegiae. Latinske kildeskrifter til Norges historie i middelalderen, Kristiania 1880, hereinafter: Theodrici Historia), cap. 18, p. 36: 
(VII, 812-15) on Caesar's proscription of the cremation of his warriors. Their bodies would thus one day transform into stars. ${ }^{42}$ After all, everything on earth is born from either of two elements - fire or water. Here, we find a fragment which is crucial to my analysis:

Plato draws attention to this alternation of periods of fire and flood; for he says that at the end of every fifteen thousand years alternately one or the other of these takes place, and that all mankind dies save for a tiny few who escape by some chance, through whom the human race is afterwards restored. This has always been the case and always will be. Plato did not, however, mean to suggest that the world is coeval with God; but just as the footprint comes from the foot, not the foot from the footprint, so both the foot and the footprint come from the same source. Likewise

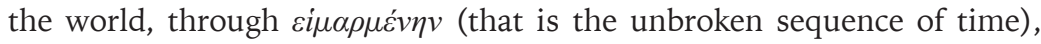
may indeed imitate eternity, but it can never attain it. Indeed, God is the most absolute eternity, infinite in form, who looks upon everything as present, whereas the world is made varied by alternations and times. ${ }^{43}$

As Tenney Frank perceptively observes, the passage cited above corresponds to fragment $22 \mathrm{c}$ in Timaeus and carries a subtle undertone of the Laws (677b). ${ }^{44}$ To put matters in perspective, Plato's Laws, unknown during the Middle Ages, discuss the true (though seemingly legendary) stories of the recurring decimation of humanity by fire or water. ${ }^{45}$ Meanwhile, the passage in Timaeus which Frank refers to

\footnotetext{
"non enim latebat philosophos, quia audierant diluvium præcessise, sæculum præsens exustione finiendum" (translations of all quotes from the chronicle after: Theodoricus Monachus, An Account).

${ }^{42}$ Theodrici Historia, 18, p. 36.

${ }^{43}$ Ibidem, 18, pp. 36f.: "Hanc vicissitudinem seculorum exustionis et eluvionis inducit Plato, dicens expletis quindecim millibus annorum eas alternatim accidere omneque humanum genus interire praeter paucissimos, qui aliquo casu evadant, unde postea reparentur homines; hoc semper extitisse et semper futurum esse. $\mathrm{Nec}$ tamen mundum Deo voluit coaevum esse, sed sicut vestigium ex pede, non pes ex vestigio, et tamen ex quo pes, ex eo vestigium: ita mundum per címarmenem, id est, continuationem temporis, imitari quidem aeternitatem, sed apprehendere non posse. Deus quippe simplicissima aeternitas, incircumscriptibilis specie, praesentialiter universitatem intuetur, mundus vero per vicissitudines et tempora diversificatur".

${ }^{44}$ Frank, 'Some Classical Quotations', 83. See also McDougall and McDougall, in Theodoricus Monachus, An Account, 83, n. 178.

${ }^{45} \Pi \lambda \alpha \tau \omega v o \varsigma$, No $\mu \omega v \gamma$, ed. John Burnett (Platonis Opera, 5, 1, Oxford, 1900), 677.
} 
obviously concerns the Egyptian priest's explanation for the Greeks' ignorance of their own history - explained by the fires, floods, and orbital shifts of celestial bodies, which had repeatedly befell them. ${ }^{46}$ Such catastrophes are also mentioned by Theodoricus, though his text does not share a sufficient linguistic resemblance to the work of Calcidius to suggest that the Norwegian chronicler had access to it (even if he cites Plato directly - "inducit Plato"). Frank himself expressed a similar view, though he has not been able to name a direct source in this context. ${ }^{47}$

Let us set aside the fact that, though Theodoricus does not cite the myth of Phaeton in his chronicle, he still refers to the Hellenic $\varepsilon i \mu \alpha \rho \mu \varepsilon \dot{\varepsilon} v \nu$ - drawn from an unspecified source - and relates the problem of natural disasters to the classic Platonic question of the nature of time and eternity. ${ }^{48}$ In my view, more interesting is

${ }^{46}$ Timaeus a Calcidio, 22b-22d, p. 14.

${ }^{47}$ Frank, 'Some Classical Quotations', 83.

${ }^{48}$ In all manuscripts of the chronicle, this Hellenic borrowing is rendered partly in Greek, and partly in Latin script (eimarmenem), while in the editio princeps from

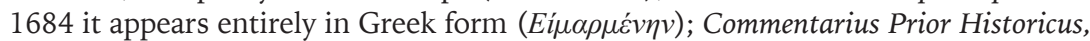
De Regibus Vetustis Norvagicis, Ducentorum circiter annorum res gestas complectens à Theodorico Monacho Nidrosiensi, ed. Bernhard C. Kirchmann (Commentarii Historici Duo hactenus inediti, Amsterdam, 1684), 36; cf. Monumenta Historica Norvegiae, 37, n. 1. Similarly, the Uppsala manuscript (S) renders pseudorex as yeudoregem, ibidem, 31, n. 1; see also Hanssen, 'Theodoricus Monachus', 93. A final paleographic resolution seems unlikely here, since Historia de antiquitate regum Norwagiensium survives in four seventeenth-century handwritten copies derived from the lost codex which Karen Skovgaard-Petersen believes to have been written in the thirteenth century in a Scandinavian scriptorium (eadem, 'Et håndskriftfund i Lübeck ca. 1620. Om den spinkle overlevering af to norske nationalklenodier', Fund og Forskning, xci [2002], 107-27, which also lists further sources on the traditions of handwritten chronicles). It is also unclear how Theodoricus came to know this

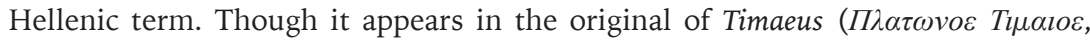
ed. Friedrich W. A. Mullachius [Fragmenta Philosophorum Græcorum, 2, Paris, 1867], 41e, p. 170), there is no trace of the word in Calcidius. Among classical

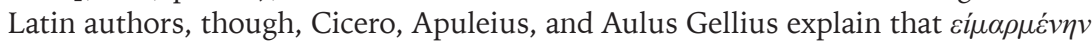
is the Greek equivalent of the word fatum, while Hermes Trismegistus names necessitas in this context (M. T. Ciceronis De Divinatione, ed. Reinhold Klotz [New York, 1879], I, 55: 125, p. 191; Apuleius, 'De Mundo', ed. Claudio Moreschini, in Apulei Platonici Madaurensis opera quae supersunt, iii: De philosophia libri [Stuttgart and Leipzig, 1991], cap. 38, p. 187; A. Gellii Noctium Atticarum libri XX, ed. Carl Hosius, i [Leipzig, 1903], lib. VII, cap. 2, $\mathbb{S} 1-3$, 283; 'Asclepius (retractatio latina libri Hermetici graeci)', ed. Claudio Moreschini, in Apulei Platonici Madaurensis 
the source for his conviction that these disasters occur every fifteen thousand years. Timaeus only proclaims that they have recurred in the past and will continue to do so in the future, and that orbital shifts are supposed to occur in an unspecified "longo interuallo". ${ }^{49}$ The only specific numbers cited by Plato and Calcidius concern the age of the Egyptian and Athenian states (eight and ten thousand years, respectively). ${ }^{50}$ As Fredrik Paasche notes, fifteen thousand years is only mentioned by Macrobius, who quoted Plato copiously in Commentarium in somnium Scipionis. ${ }^{51}$ Macrobius relates the question of the nature of time to the recurrence of major natural disasters - floods and fires - and names the cause of their appearance: the mutual influence of two elements, fire and water. ${ }^{52}$ The Norwegian historian shared his conviction.

opera, iii, cap. 19, 58; cap. 39-40, pp. 83-4). The distance between Theodoricus' continuatio temporis and fatum does not seem particularly large - especially as the aforementioned four authors explain the latter word as the temporal continuity between events. In the Norwegian monk's work, however, Eí $\alpha \rho \mu \varepsilon \dot{v} \eta v$ does not connote determinism, but rather the manner in which the temporal world imitates eternity. Analogies between Theodoricus, Calcidius, and Macrobius are discussed in Paasche, 'Über Rom', 137 ff. The question clearly requires further research. A cursory query indicates that the term simplex aeternitas is used in reference to God in, e.g., Anselm of Canterbury, Epistula de incarnatione verbi, ed. Franciscus Salesius Schmitt (S. Anselmi Cantuariensis archiepiscopi Opera Omnia, 2, Edinburgh, 1946), cap. 15, 33. Later instances are found in Thomas Aquinas, In Octo libros Physicorum Aristotelis Commentarium, ed. Mariano Maggiolo (Torino, 1954), VIII, lectio 3, no. 3, p. 515.

${ }^{49}$ Timaeus a Calcidio, 22b-23b, p. $14 \mathrm{ff}$.

${ }^{50}$ Ibidem, 23b, p. 15: "priorem uestram annis fere mille ex indigete agro et Uulcanio semine, posteriorem hanc nostram octo milibus annis post, sacris delubrorum apicibus continetur". See also Brisson, Plato the Myth Maker, 22, 25ff.

${ }^{51}$ Paasche, 'Über Rom', 137 ff. (in reference to: Matthaeus Schedler, Die Philosophie des Macrobius und ihr Einfluss auf die Wissenschaft des christlichen Mittelalters. Dargestellt und philosophiegeschichtlich untersucht [Münster, 1916], 110, 122). Apart of Fredrik Paasche, as far as I know, no one wagered that Theodoricus may have known the commentary by Macrobius, a widely-read work during the Middle Ages. While the chronicler obviously does not cite Macrobius, his references to Plato may have been derived from the former. The works of Macrobius were also found in the library of the Abbey of St Victor in Paris, which Theodoricus is thought to have visited (Paris, Bibliothèque nationale, Ms. lat. 14768, fol. 133v).

${ }^{52}$ Ambrosius Theodosius Macrobius, 'Commentarii in Somnium Scipionis', in idem, Opera, ed. Franciscus Eyssenhardt (Leipzig, 1893), II, 10: 9-10, p. 618 and 10: 10-14, pp. $618 \mathrm{ff}$. 
Though the fifteen-thousand-year interval is mentioned by Macrobius, the context is different than in Theodoricus. Discussing the findings of physicists ("ut physici uolunt", "sicut adserent physici"), Macrobius attributes this temporal perspective to certain astronomical phenomena rather than to natural disasters, supposedly in reference to the cosmic cycle (annus mundanus), with whose conclusion all stars return to their original locations. ${ }^{53}$ Furthermore, this time-frame (counted from the death of Romulus) corresponds to the supposed timing of the disappearance of the Sun. ${ }^{54}$ One should note that Macrobius derived his name for that cycle from Cicero (annus magnus), who, however, described its length in various terms, never explicitly citing fifteen thousand years. ${ }^{55}$

The term annus mundanus appears in works of many other authors of late Antiquity and the Middle Ages, such as Pseudo Bede, who, like Macrobius, used it in reference to natural disasters. ${ }^{56}$ It was only with William of Conches, however, that the term began to connote recurring floods. This twelfth-century philosopher, a representative of the Chartres school, states in his glosses to the Calcidian Timaeus that celestial bodies at times tend to deviate from their orbits, provoking fires that wreak havoc on the earth. Yet, he immediately notes that the phenomenon does not occur on a daily basis, but rather in intervals ("longo intervallo"). Indicating a clear debt to Macrobius, he specifies that "as physicists say, a flood occurs every fifteen thousand years". ${ }^{57}$

${ }^{53}$ Ibidem, II, 11: 10-11, pp. $621 \mathrm{ff}$.

${ }^{54}$ Ibidem, II, 11: 15, pp. $622 \mathrm{ff}$.

${ }^{55}$ For more on this subject, see Paul R. Coleman-Norton, 'Cicero's Doctrine of the Great Year', Laval théologique et philosophique, iii, 2 (1947), 293-302, esp. 301.

${ }^{56}$ This concerns only authors active before the end of the twelfth century; see S. Augustini Enarrationes in Psalmos, in PL, vol. XXXVII, in psalmum CIV, cap. 6, col. 1393; [Pseudo Bede], De mundi coelestis terrestrisque constitutione liber, in PL, vol. XC, col. 906; Honorius Augustodunensis, De Imagine Mundi, in PL, vol. CLXXII, II, 70, col. 155; Hugo de s. Victore, In Salomonis Ecclesiasten homilice XIX, in PL, vol. CLXXV, homilia II, col. 144; Gilberti Foliot episcopi Londinensis Expositio in Cantica canticorum, in PL, vol. CCII, col. 1175; other instances at the Am 3. Mai des Jahres 2000 begann offensichtlich ein neues "Weltenjahr" website, http://12koerbe. de/arche/annus.htm [Accessed: May 8, 2015). This account is also discussed in Paasche, 'Über Rom', 137 ff.

${ }^{57}$ Guillelmi de Conchis Glosae super Platonem, ed. Édouard Jeauneau (Corpus Christianorum. Continuatio Mediævalis, 203, Turnhout, 2006), I, 27, p. 51: "Vere est res uera quia fit exorbitatio, quando scilicet nimius feruor ad nostram habitabilem 
The most noteworthy aspect of this quote is the reference to physicists, borrowed from Commentarium in Somnium Scipionis. Incidentally, William repeats it when discussing the fifteen-thousand-year cosmic cycle culminating with the return of all celestial bodies to the places of their creation by God. ${ }^{58}$ Of note is his conviction that dangerous astronomical phenomena are logically connected with fires as well as floods. Elsewhere in his glosses, the philosopher explains the disasters by claiming that all water and fire on earth derives from singular sources known only to a handful of men. Both elements exert mutual influences; no ill will come of either so long as they remain in equilibrium, but once the balance is lost, fires and floods break out. The two phenomena are also correlated, which is why they follow one another. ${ }^{59}$

Here, in my view, is the direct source of Theodoricus Monachus's insight, which scholars had heretofore neglected. After all, William of Conches was the first to extend the idea of fifteen-thousand-year cycles from astronomical phenomena to natural disasters. While Theodoricus could have performed the same gesture without recourse to William, by drawing independent conclusions from a reading of Macrobius or Pseudo Bede, it is easier to cast William as the mediator. One should also note that the chronicler developed ideas put forward by the Chartres-based author of commentaries on Timaeus. While the latter continues to identify a logical connection between the movement of celestial bodies and the occurrence of natural disasters, Theodoricus eschews it by identifying floods and fires as independent

transit. Sed ne aliquis putaret cotidie hoc contingere, subiungit: longo intervallo, quia, ut dicunt phisici, post quindecim milia annorum diluuium contingit" (with no access to Jeauneau's edition, I cite after: <http://clt.brepolis.net/llta/Default. aspx> [Accessed: March 9, 2015]; italics mark fragments of William's commentary derived from Calcidius).

${ }^{58}$ Ibidem, I, 103, p. 182: "Et est mundanus annus quando omnes stellae et planetae ad eadem loca simul reuertuntur in quibus a Deo creati sunt. Et dicunt philosophi quod hoc fit post quindecim milia annorum".

${ }^{59}$ Ibidem, I, 25, pp. 46-8. The vortex that provided the source for "omnis aquarum abundantia" is also mentioned by Theodoricus. The chronicler gives it the name "Charybdis" and locates it near the Orcades based on the Book of Genesis, Chrysippus of Soli, Pliny the Elder, and Paul the Deacon (Theodrici Historia, cap. 16-17, pp. $31 \mathrm{ff}$.). This account is wider discussed in Paul Lehmann, Skandinaviens Anteil an der lateinischen Literatur und Wissenschaft des Mittelalters, ii (München, 1937), 72; Johnsen, Om Theodoricus, 32 ff., 47. 
phenomena unrelated to the position of stars; even the term annus mundanus does not figure in his work.

The identification of Glosae super Platonem by William of Conches as a direct source for Theodoricus also raises the question of the impact of the Chartres school on the chronicler. Several clues indicate a connection: the aforementioned reference aside, Theodoricus may have studied at the Abbey of St Victor in Paris. Sadly, the time or extent of his stay in France is unknown. Still, one may well claim that he must have acquainted himself with most of the sources he cites at the Parisian library. ${ }^{60}$ Further research is required before a definite answer can be provided to the question whether Theodoricus read the work by the philosopher from Chartres specifically at the Abbey of St Victor. At present, claims of any broader influence of the Chartres school on the formation of the chronicler beyond the aforementioned quote are still unfounded. ${ }^{61}$

\section{V}

Let us now return to the 'Platonic' passage in the Historia de antiquitate regum Norwagiensium. The belief that the citations from the Ancient philosopher this text includes are not drawn directly from Calcidius - as is the case in the work by Kadłubek - but rather from the Glosae by William of Conches finds support in the narrative context of the quotes. In fact, Timaeus names natural disasters as a direct cause of the Greeks' obliviousness of their own history.

${ }^{60}$ The hypothesis was put forward by Johnsen, Om Theodoricus, 56 ff. A sixteenth-century catalogue locates two copies of Timaeus at the library of the Abbey of St Victor (Ms. lat. 14768, fol. 165v), along with a copy of the commentaries by Calcidius, which Johnsen had missed (fol. 37r). Furthermore, Timaeus is cited by Hugo of St Victor, though he seems unlikely to have acted as a mediator here given the disparity in the subject matter of works by him and Theodoricus (Hugo de s. Victore, Adnotationes elucidatorice in Pentateuchon, in PL, vol. CLXXV, cap. 1, col. 31; idem, Eruditionis Didascalica libri septem, in PL vol. CLXXVI, I, cap. 2, col. 741). For more on the Parisian trail, see Johnsen, Om Theodoricus, 32; Vladimir P. Polách, Historie o starých norských králich. Středověké Norsko a Skandinávie $v$ kronice mnicha Theodorika (České Budějovice, 2014), 113, 155, n. 353.

${ }^{61}$ I was only able to ascertain that the Parisian library included a copy of William's Philosophia (Ms. lat. 14768, fol. 91r). For more on resonances of Chartres in Historia Norwegie, a work produced independently from Theodoricus, see Lars B. Mortensen, 'Commentary', in Historia Norwegie, 132. 
Incidentally, the same question was also addressed by Kadłubek, who stated that the shining glory of the old res publica would prevail through "tot seculorum tempestates" ${ }^{62}$ Theodoricus, in turn, was drawn to these tempestates (specifically: exustiones et eluviones) not because of their immediate ties to historical memory, but merely due to their status as recurring natural events, an object of knowledge of philosophers. ${ }^{63}$

The fact that the Norwegian chronicler referred to William's glosses may not necessarily exclude the possibility of his familiarity with Timaeus in Calcidius's translation (for instance, a single codex may have included both works). The treatise could have provided him with less apparent insights. In my view, the account of the history of Norway by Theodoricus is palpably structured by the Platonic concept of memory of ancient deeds from the very beginning. Here are the opening sentences of the prologue to the chronicle, addressed to the Archbishop of Niðaróss, Eysteinn Erlendsson:

I have deemed it worthwhile, noble sir, to write down in brief these few details concerning the ancient history of the Norwegian kings, as I have been able to learn by assiduous inquiry from the people among whom in particular the remembrance of these matters is believed to thrive - namely those whom we call Icelanders, who preserve them as much celebrated themes in their ancient poems. And because almost no people is so rude and uncivilized that it has not passed on some monuments of its predecessors to later generations, I have thought it proper to record for posterity these relics of our forefathers, few though they are. ${ }^{64}$

${ }^{62}$ Vincent, Chronica, I, 1: 1-2, p. 6. The same passage is highlighted by Wojtowicz, 'Ateny i pamięć', 88, n. 4.

${ }^{63}$ Theodrici Historia, cap. 18, p. 36.

${ }^{64}$ Ibidem, 'Prologus', p. 3: “Operæ pretium duxi, vir illustrissime, pauca hæc de Antiquitate Regum Norwagiensium breviter annotare, et prout sagaciter perquirere potuimus $\mathrm{ab}$ iis, penes quos horum memoria præcipue vigere creditur, quos nos Islendingos vocamus, qui hæc in suis antiquis carminibus percelebrata recolunt. Et quia pene nulla natio est tam rudis et inculta, quæ non aliqua monumenta suorum antecessorum ad posteros transmitterit, dignum putavi, hæc pauca licet, majorum nostrorum memoriæ posteritatis tradere". On the prologue, cf. Hanssen, 'Theodoricus Monachus', 71-8; Sverrir Tómasson, Formálar íslenskra sagnaritara á miðöldum. Rannsókn bókmenntahefðar (Reykjavík, 1988), ad indicem: Theodricus Monachus; Bagge, 'Theodoricus Monachus: Clerical Historiography', 115-17. 
Clearly, Theodoricus sought to record the history of the rulers of Norway and preserve it for posterity. ${ }^{65}$ There was no received tradition of writing he could fall back on since none existed at the time, as the entirety of his work suggests. In practice, the only source he could use were the "ancient poems" in which Icelanders preserved the memory of the kings of Norway. ${ }^{66}$ The chronicler then determines that his account would begin with the first king, Harald Fairhair, as dynastic succession was not established in Norway prior to his rise to power. ${ }^{67}$ This, however, did not signify an absence of men distinguished by their righteousness, fame, and unmatched combativeness in the country further into the past. On the contrary, testes idoneiHugo of St Victor and Sigebert of Gembloux - recorded historical Norse expeditions by sea to Gaul, culminating in pillage and devastatation. ${ }^{68}$ Perhaps not coincidentally, Theodoricus echoes Timaeus by

65 Theodoricus's concept is also discussed by Pernille Hermann, 'Concepts of Memory and Approaches to the Past in Medieval Icelandic Literature', Scandinavian Studies, lxxxi, 3 (2009), 289-90; Stephen Mitchell, 'Memory, Mediality, and the "Performative Turn". Recontextualizing Remembering in Medieval Scandinavia', Scandinavian Studies, lxxxv, 3 (2013), 290; Bruce Lincoln, Between History and Myth: Stories of Harald Fairhair and the Founding of the State (Chicago and London, 2014), 109 ff.; Banaszkiewicz, 'Master Vincent'.

${ }^{66}$ Thus far, scholars accepted Theodoricus's claims that the chronicler lacked access to written sources on the history of Norway (most recently Lars B. Mortensen, review of: Theodoricus Monachus, An Account, Maal og Minne [2000], 101-4) and merely borrowed copiously from identifiable poems by skalds (see e.g. Lange, Die Anfänge, 55-98). However, one should take note that "ancient poems" are a common trope of ancient and medieval history writing. One famous example are the Gothic carmina prisca pene storicu ritu, in which ancient history was recolitur (Iordanis Getica, ed. Theodor Mommsen [MGH AA, 5, 1, Berlin, 1882], 4, 28, p. 61). In fact, Timaeus itself states that Critias the Younger heard his grandfather's tale at a ceremony involving the declamation of "multa carmina tam ueterum quam nouorum poetarum", Timaeus a Calcidio, 21b, p. 12.

${ }^{67}$ Theodrici Historia, 'Prologus', p. 3: "Sed quia constat, nullam ratam regalis stemmatis successionem in hac terra extitisse ante Haraldi Pulchre-comati tempora, ab ipso exordium fecimus" (Because it is clear that no established succession of the royal line existed in this land before the time of Haraldr Fair-hair, I have begun with him).

${ }^{68}$ Ibidem, 3 ff.: "Non quia dubitaverim etiam ante ejus ætatem fuisse in hac terra viros secundum præsens sæculum probitate conspicuos ... . Ad quod probandum testes ciebo idoneos" (And I have not done this because I doubted that before his day there were in this land men who, by the standards of the present age, were distinguished by their prowess ... . To prove this, I shall summon suitable 
placing victorious overseas expeditions at the dawning of the most ancient history.

The chronicler's account, however, is marred by a certain gap which prevents him from lauding the glory of the Vikings as one that "glows with a curious radiance, which couldn't be extinguished by the tempests of time". ${ }^{69}$ Though Theodoricus knew of the Gallic expeditions of the Normans from his readings, he referred to the uncharacteristically pessimistic discourse of Boethius, noting that the memory of those deeds had perished due to an absence of writings ("scriptorum inopia"). ${ }^{70}$ Wherefore such contrast in his approach to ancient history? The answer seems to reside in the sentence that

witnesses). Here follow quotes on Viking expeditions to Gaul (drawn, as indicated, from: Chronica Sigeberti Gemblacensis a. 381-1111, ed. Ludovicus C. Bethmann (MGH SS, 6, Hannover, 1844), s.a. 853, p. 340; Hugo de s. Victore [recte: Richardus de s. Victore], Priorum Excerptionum libri decem, in PL, vol. CLXXVII, X, 10, col. 284). In the end, Theodoricus offers the following comment: "Liquet itaque, virorum optime, ex his fuisse etiam ante tempora Haraldi in hac terra in bellicis rebus potentes viros" (It is therefore clear from these accounts, O best of men, that before the days of Harald there were in this land men mighty in war).

${ }^{69}$ Vincent, Chronica, I, 1: 1, p. 6: "mira tamen rutilantia rutilat, que tot seculorum tempestatibus extingui non potuit".

${ }^{70}$ Theodrici Historia, 'Prologus', 3 ff.: "Non quia dubitaverim etiam ante ejus ætatem fuisse in hac terra viros secundum præsens sæculum probitate conspicuos, quos nimirum, ut ait Boëthius, clarissimos suis temporibus viros scriptorum inops delevit opinio . Liquet itaque, virorum optime, ex his fuisse etiam ante tempora Haraldi in hac terra in bellicis rebus potentes viros: sed, ut diximus, illorum memoriam scriptorum inopia delevit" (And I have not done this because I doubted that before his day there were in this land men who, by the standards of the present age, were distinguished by their prowess, since certainly, as Boethius says, "reputation without authors has effaced those men who were very famous in their own times ... ." It is therefore clear from these accounts, O best of men, that before the days of Harald there were in this land men mighty in war, but that, as I have said, a dearth of writers has effaced any remembrance of them). The imperfect quotation comes from: Boethius, De Consolatione Philosophice, ed. Wilhelm Weinberger (Corpus Scriptorum Ecclesiasticorum Latinorum, 67, Vienna, 1935), II, 7. For a debate on the quote, see Espen Karlsen and Kyrre Vatsend, 'On Theodoricus Monachus' Use of Late Classical Authors', Collegium Medievale, xvi (2003), 255-8; Egil Kraggerud, 'Boëthius and the Preface of Theodoricus' "Historia" - "opinio" versus "oblivio" once again', Collegium Medievale, xvii (2005), 144-7 (which also includes references to earlier studies by Kraggerud). On further analogies, see Eiliv Skard, Målet $i$ "Historia Norwegiae" (Oslo, 1930), 75; Hanssen, 'Theodoricus Monachus', 75. 
justifies the commencement of an account of Norwegian history with Harald. Prior to his ascent to the throne, the country did not have "nullam ratam regalis stemmatis successionem". This suggests a strict correlation between dynastic succession and the persistence of memory enabling the reconstruction of ancient history. Here, my convictions are additionally supported by a reading of the opening sentences of Kadłubek's chronicle, where Master Vincentius observes that the virtues of the old res publica were not recorded in ancient scrolls. ${ }^{71}$ He follows this statement by noting that the Lechites "were not ruled by ... either descendants of the common folk, or self-proclaimed rulers, but by hereditary dukes", whose memory shone through the ages against all peril, even in the absence of written records, which would normally result in the forgetting of ancient deeds. ${ }^{72}$

The treatment to which Theodoricus subjects ancient Norwegian history in his narrative continues to puzzle, particularly since other twelfth-century Scandinavian chroniclers reconstruct Harald Fairhair's genealogy up to the mythical progenitor of the Yngling dynasty, Yngvi. ${ }^{73}$ Theodoricus makes no such attempt, even though the name of Harald's father, Halfdan the Black, is mentioned ${ }^{74}$; instead, he stresses the absence of dynastic succession in Norway prior to Harald's ascent to the throne. Did his Icelandic sources evade this question? If Icelanders were tasked - in the represented world of

${ }^{71}$ Vincent, Chronica, I, 1, 1, p. 6: "non scripture quidem membranulis, set clarissimis gestorum radiis patres conscripti illustrauere".

72 Ibidem: "Non enim plebei aborigines, non uendicarie illi principate sunt potestates, set principes succedanea." I am more interested in the declarations of both Theodoricus and Kadłubek, that the persistence of memory depends on dynastic succession, than in the practical impact of a linear succession on the exposition in both chronicles; for more on this subject, see Marek Cetwiński and Jacek S. Matuszewski, 'Metodologia wyrażania pożądanej koncepcji ustrojowej w kronice Wincentego i jej współczesne implikacje’, in Dąbrówka and Wojtowicz (eds.), Onus Athlanteum, 416-22; Żmudzki, 'De huius rei publice origine'; Foote, 'Introduction', vii ff.

${ }^{73}$ Cf. a listing of examples with an in-depth interpretation in: Svend Ellehøj, Studier over den celdste norrøne historieskrivning (København, 1965), 109-41; Anthony Faulkes, 'Descent from the Gods', Mediaeval Scandinavia, xi (1978-1979), 92-125; Joan Turville-Petre, 'The Genealogist and History: Ari to Snorri', Saga-Book, xx (1978-1981), 7-23.

${ }^{74}$ Theodrici Historia, 1, p. 6: "Haraldus Pulchre-comatus, filius Halfdan Nigri" (Haraldr Fair-hair, son of Halfdan the Black). 
the chronicle - with preserving the memory of the kings of Norway, why would they not include ancient rulers, as well? Is it not more likely that the chronicler selected the information that best suited his assumptions? Arguments ex silentio are of no avail here, as the ancient rulers of Uppland were not given even a single mention in the chronicle. ${ }^{75}$ Instead, Theodoricus limited his discussion of ancient history to the question of historicity of certain just men who had once raided Gaul.

In accordance with his initial declaration, the chronicler opens his historical narrative with Harald in spite of having access to only limited factual information - the starting date of Harald's reign, the duration of his rule, his name, cognomen, and patronymic, as well as his military and political achievements. ${ }^{76}$ Theodoricus owed a part of that knowledge to the Icelanders, the most learned of the peoples of the North. ${ }^{77}$ Yet, in his view, the information was not incontrovertible since there were no written sources to support it. ${ }^{78}$ Thus, a declared reliance on oral traditions could not guarantee the truthfulness of the account. Before that, Theodoricus also stressed that the veracity of his own work was guaranteed by those who provided him with the information he used, available to him "non visa, sed audita". ${ }^{79}$

${ }^{75}$ For comments on the silence of Theodoricus, cf. Bagge, 'Theodoricus Monachus: The Kingdom', 74 ff.; Shami Ghosh, Kings' Sagas and Norwegian History. Problems and Perspectives (Leiden and Boston, 2011), 66-70; Polách, Historie, 197.

${ }^{76}$ Similarly in Lincoln, Between History, 111.

77 Theodrici Historia, 1, p. 6: "Hunc numerum annorum Domini investigatum, prout diligentissime potuimus ab illis, quos nos vulgato nomine Islendingos vocamus, in hoc libro posuimus: quos constat sine ulla dubitatione præ omnibus Aquilonaribus populis in hujusmodi semper et peritiores et curiosiores extitisse" (In this book I have set down the count of years which I ascertained by making the most diligent inquiries I could among those whom we in our language call Icelanders. It is well known that they without doubt have always been more knowledgeable and more inquisitive in matters of this kind than all the other northern peoples).

${ }^{78}$ Ibidem: "Sed quia valde difficile est in hisce ad liquidum veritatem comprehendere, maxime ubi nulla opitulatur scriptorum autoritas, istum numerum nullo modo volumus præjudicare certiori, si reperiri valet" (But because it is exceedingly difficult to arrive at the pure truth in such matters, especially where no written authority provides assistance, I by no means wish to pronounce in favour of this date rather than a more certain one, if one can be found).

${ }^{79}$ Ibidem, 'Prologus', p. 4: "Veritatis vero sinceritas in hac nostra narratione ad illos omnino referenda est, quorum relatione hæc annotavimus: quia nos non visa 
To return to the Icelandic sources of Thedoricus, I contend that they serve a similar role in his work as the knowledge of the Egyptian priests does in Timaeus. Indeed, the Norwegian chronicler uses the same term as Calcidius to describe the memory of which the Icelanders were depositaries: praecipua (here, it seems irrelevant that Calcidius used the adjective, while Theodoricus uses the adverb).$^{80}$

sed audita conscripsimus" (However, the degree of pure truth in my present narrative must be placed entirely at the door of those by whose report I have written these things down, because I have recorded things not seen but heard); cap. 34, p. 68: "Pauca haec de antecessoribus nostris rudi licet stylo, ut potui, perstrinxi, non visa sed audita retractans. Quapropter si quid dignatus fuerit haec legere, cui forte displicuerit sereim rerum gestarum sic me ordinasse, quaeso ne me mendacii arguat, quia aliena relatione didici quod scripsi. Et sciat pro certo me istarum rerum relationem alium potius voluisse quam me; quod quia hactenus non contigit, me malui quam neminem" (I have touched upon these few details concerning our forefathers to the best of my ability, though with an inexpert pen, and treated not what I have seen, but what I have heard. For this reason, if anyone should condescend to read this, and should perhaps be displeased that I have arranged this account as I have, I beg that he should not accuse me of falsehood, because I have learned what I have written from the report of others. And let him know that I would assuredly have rather seen someone other than myself act as the chronicler of these events, but since to date this has not happened, I preferred that it should be me rather than no one). For a discussion with commentary, see Hanssen, 'Observations on Theodoricus', 172 ff.; idem, 'Theodoricus Monachus', 75 ff.; Lange, Die Anfänge, 104 ff.; Krzysztof Pomian, Przeszłość jako przedmiot wiary. Historia i filozofia $w$ myśli średniowiecza (Warszawa, 2009), 46-78.

80 Theodrici Historia, 'Prologus', p. 3: the chronicler intended to "pauca hæc de Antiquitate Regum Norwagiensium breviter annotare, et prout sagaciter perquirere potuimus ab iis, penes quos horum memoria præcipue vigere creditur"; Timaeus a Calcidio, 22b, p. 13: "Denique cum in conuentu sacerdotum, penes quos praecipua sit memoria uetustatis". I would not go so far as to say that the use of the common term penes quos by Theodoricus in this context along with the words memoria and praecipue indicates a covert quotation from Calcidius. Instead, I believe that those two passages are bound by a deeper ideological connection, perhaps resulting from an inspiration from the reading of the older of the two (which I seek to prove below). Cf. with the method applied by Zenon Kałuża in a study of similar source material and critical responses in: idem, Lektury filozoficzne, passim; Edward Skibiński, 'Idemptitas est mater societatis. Kilka uwag o konstrukcji Kroniki polskiej Mistrza Wincentego Kadłubka (na marginesie pracy profesora Zenona Kałuży)', Cistercium Mater Nostra, ii, 2 (2008), 65-73; Wiesław Pawlak, “"Grecyzm Juwenala”. Glosa do prologu Kroniki Mistrza Wincentego', Śląskie Studia Polonistyczne, 2 (4) (2013), 25 ff.; Jacek Banaszkiewicz, 'Dyskusja', in Dąbrówka and Wojtowicz (eds.), Onus Athlanteum, 280-2; idem, 'Master Vincent'. 
To reiterate, Timaeus compares Athenians to children bereft of "an ancient knowledge", who know nothing of their own ancient history because their ancestors were decimated during the flood. That history was remembered 'for them' by Egyptian priests whose memory depended on inscriptions in temples. ${ }^{81}$ Theodoricus, on the other hand, states that, with Norwegians bereft of their own chronicle, the memory of their kings is maintained and renewed by Icelanders "in suis antiquis carminibus"; Norwegians themselves, on the other hand, are encumbered by the burden of their recent barbarity: as Theodoricus observes, few "rude and uncivilised" peoples abstain from committing remembrances of their ancestors to posterity. ${ }^{82}$

In both instances, then, we are dealing with a 'particular memory of antiquity' (praecipua memoria vetustatis) or 'memory propagated in a particular manner' (memoria praecipue vigere), distinguished by being deposited with kindred peoples of Athenians and Norwegians - Egyptians and Icelanders, respectively. ${ }^{83}$ The existence of this "particular memory" allowed Plato and Theodoricus (as well as Kadłubek) to reach farther into the ancient past. Neither had any other means of gaining access to ancient deeds since both Athenians, Norwegians, and Lechites lacked their own scriptural historiographic tradition. While Plato and Kadłubek never questioned the veracity of tales of

${ }^{81}$ For more on Egyptian priests, see also Dombrowski, 'Atlantis and Plato's Philosophy', 121 ff.; Brisson, Plato the Myth Maker, 25; Kałuża, Lektury filozoficzne, 108; Banaszkiewicz, 'Master Vincent'.

${ }^{82}$ Theodrici Historia, 'Prologus', p. 3. Cf. the reservation made by Gallus Anonymus: "Quodsi reges Polonos vel duces fastis indignes annalibus iudicatis, regnum Polonie procul dubio quibuslibet incultis barbarorum nationibus addicatis", Galli Anonymi Cronicae et gesta ducum sive principum Polonorum, ed. Karol Maleczyński (MPH, N.S., 2, Kraków, 1952), III, epistola, 121. That Pagans "praeterita autem aut obliuiscantur aut nesciant" is asserted by: Orose, Histoires (contre les païens), ed. Marie-Pierre Arnaud-Lindet, i (Paris, 2003), I, 'Prologus', 9, p. 8.

${ }^{83}$ Let us remember that Egyptians took pride in their kinship to Athenians; see Timaeus a Calcidio, cap. 21e, 13. While Theodoricus, on the other hand, clearly distinguished between Icelanders and Norwegians (Theodrici Historia, 12, p. 19-21), he was also aware of the common origin of both peoples (cap. 3, p. 8-9). Bruce Lincoln seems to downplay the latter fact when he comments references to Icelandic sources in the chronicle in these words: "in his search for knowledge of the deeper past, he [Theodoricus] depends on Icelanders, who were not only outsiders (is it still 'our' history if we get it from 'them'?), but of all outsiders, the ones most hostile to kings, kingship, and Harald Fairhair above all" (Lincoln, Between History, 110). 
ancient past, though, Theodoricus expressed fundamental doubts that the information making up his work was incontrovertible. ${ }^{84} \mathrm{His}$ objections derived from the fact that the oral sources he relied on found no support in written documents. ${ }^{85}$

The "foreign" origin of the memory of ancient history may discredit the inheritors of that history. In Timaeus, as already mentioned, Greeks were likened to children ignorant of their own past; Kadłubek echoed that sentiment by translating a difference of ethnicity to that between subsequent generations - namely, by inscribing it onto the relationship between Jan and Mateusz on the one hand and the elder on the other. Meanwhile, Theodoricus transforms the "childishness" of Athenians and Kadłubek's hierarchs by altering the metaphor: namely, by stating that only barbarian peoples have no history of their own, or at least no recorded history. He was also conscious of the far Northern

${ }^{84}$ The tale of Critias the Younger was termed as "miram quidem sed plenam fidei ueritatisque rem", Timaeus a Calcidio, 21a, p. 12. Yet, once he heard it, Socrates ascertained its veracity: "magnificum uero illud non fictam commenticiamque fabulam, sed ueram historiam" (cap. 27a, p. 19). On the veracity of Critias's tale, see Christopher Gill, 'The Genre of the Atlantis Story', Classical Philology, lxxii, 4 (1977), 287-304; idem, 'Plato's Atlantis Story and the Birth of Fiction', Philosophy and Literature, iii, 1 (1979), 64-78; Gerard Naddaf, 'The Atlantis Myth: An Introduction to Plato's Later Philosophy of History', Phoenix, xlviii, 3 (1994), 189-209, esp. 194 ff.; Brisson, Plato the Myth Maker, 14 ff. Luc Brisson writes of the often elusive ironic subtext of the Platonic account of ancient history, aimed against the Sophists. A medievalist can do little more than to accept Brisson's point. Kadłubek, on the other hand, invokes the words "rem miram set fidei plenam" from Timaeus in an account of the victory of Lechites over Alexander the Great; see Vincent, Chronica, I, 10: 1, p. 17; Kałuża, Lektury filozoficzne, 112 ff., 296, 436-41. In Kałuża's view, Plato and Kadłubek ascertained the veracity of tales they had, in fact, "made up". The Polish translator of Plato's works, Władysław Witwicki, shared that opinion in Platon, Timaios. Kritias (Kęty, 2002), 23, n. 8. However, it seems more fitting to say, that both the Ancient and the medieval tales were fashioned from certain topical elements. On the trope of ascertaining veracity in medieval historiography, see Jeanette M. A. Beer, Narrative Conventions of Truth in the Middle Ages (Genève, 1981).

${ }^{85}$ For a broad analysis of the approach of medieval historians from this angle, see Pomian, Przeszłość, 79-107. However, Pomian decisively simplifies the matter by claiming that "Oral and scriptural traditions were ... equivalent, and the differences between them were treated [in medieval history-writing] as merely technical, rather than epistemologically significant" (p. 100; more broadly, p. 84). The example of Theodoricus (and many others) shows that these differences were treated as 'epistemologically significant', indeed. 
origin of Norwegians and their ignorance of the time and location of the baptism of their greatest ruler - St Olaf. However, the way in which the chronicler dealt with the question of the lowly provenance of his people, making a virtue of it, merits a separate analysis. ${ }^{86}$

The trope of Icelandic "experts" on ancient history of Scandinavian kingdoms must have been common in Theodoricus's time since it is also invoked by two contemporary Danish chroniclers - Sven Aggesen and Saxo Grammaticus - regardless of their possible familiarity with Timaeus. ${ }^{87}$ Thus, Sven opens his account much like Theodoricus does - by observing that the ancient history of Danish kings has not yet been written. ${ }^{88}$ The chronicler, therefore, undertakes to preserve it for posterity with all reservations concerning his own skills as a writer. ${ }^{89}$ The fulfilment of this operation is made possible by the fact that his ancient ancestors had placed the history in 'eternal remembrance'. ${ }^{90}$ His historical narrative, like that of Theodoricus, begins with the first king, Skiold, who was also the first to become a part of the eternal

${ }^{86}$ For now, I can point to the following works: Bagge, 'Theodoricus Monachus: Clerical Historiography', passim; idem, 'Theodoricus Monachus: The Kingdom', passim; Rafał Rutkowski, 'In illa terra, ubi nullus antiquitatum unquam scriptor fuerit. Historia jako składnik tożsamości ludu cywilizowanego (na przykładzie opowieści Mnicha Teodoryka o okolicznościach chrztu Olafa Świętego)', Studia Źródtoznawcze, liii (2015), 3-15.

${ }^{87}$ The fact was observed a while ago already; see e.g. Israel Gollancz, 'Introduction', in Hamlet in Iceland, being the Icelandic Romantic Ambales Saga (London, 1898), xxii ff.; Eyvind F. Halvorsen, 'Theodoricus Monachus and the Icelanders', in Kristján E. Ritsjóri (ed.), Pridji Vikingafundur (Reykjavik, 1958), 148 ff.; Lange, Die Anfänge, 97-8; McDougall and McDougall, in Theodoricus Monachus, An Account, 55, n. 3; Ghosh, Kings' Sagas, 20; Lincoln, Between History, 260, n. 10.

${ }^{88}$ Sven was probably a cleric (archdeacon?) of noble birth close to Absalon, Archbishop of Lund. Few works on him exist; see e.g. Eric Christiansen, 'Introduction', in The Works of Sven Aggessen, Twelfth-Century Danish Historian (London, 1992), 1-30; Lars B. Mortensen, "Historia Norwegie" and Sven Aggesen: Two Pioneers in Comparison', in Ildar H. Garipzanov (ed.), Historical Narratives, 57-70.

${ }^{89}$ Svenonis Aggonis Filii Brevis Historia Regvm Dacie (referred to further as Svenonis Historia), ed. Martin C. Gertz (Scriptores Minores Historiæ Danicæ Medii Ævi, 1, København, 1917), 'Prologus', p. 94.

${ }^{90}$ Ibidem, p. 96: "Illum igitur nunc nostra relexat oratio, quem priscorum annositas iugi primum commendauit memorie". See Banaszkiewicz, "Master Vincent' (which makes the connection between Theodoricus, Sven, and Vincentius, but without mentioning the Platonic inspirations of the former). (The Works of Sven Aggessen, 'Preface', p. 49: "And so our tale will now restore to life the man whom our remotest forebears first commended to eternal remembrance".) 
remembrance. Here, the chronicler invoked Icelandic poems to prove that "our kings were named Skioldunger" in honour of the originator of the dynasty. ${ }^{91}$ A passing reference to modi hislandienses, combined with the earlier mention of the absence of written sources on Danish history, plainly indicates that Icelanders were seen as experts in ancient histories of Scandinavian kingdoms.

The interest of Icelanders in 'foreign history' was particularly firmly stressed by Saxo Grammaticus, a writer of much greater renown among scholars of medieval history. ${ }^{92}$ The author of Gesta Danorum notes that Icelanders - though plagued by material scarcity - were used to devoting their lives to broadening their knowledge of the history of other peoples. Indeed, they took as much (or even more) pleasure in debating the achievements of others as in demonstrating their own. Should this be taken to mean that they did not have a history of their own? Finally, Saxo concedes that Icelandic tales constituted a vital source for his own historical account and a guarantee of its veracity since the Icelanders possessed "such knowledge of the ancient" ("tanta vetustatis peritia") ${ }^{93}$

${ }^{91}$ Svenonis Historia, 1, p. 96: "Skiold Danis didici primum prefuisse; et ut eius alludamus uocabulo, iccirco tali functus est nomine, quia uniuersos regni terminos regie defensionis patrocinio affatim egregie tuebatur. A quo primum modis Hislandiensibus Skioldunger sunt reges nostri nuncupati" (I have learned that Skiold was the first man to rule over the Danes, and if we may make a pun on his name, he was called this because he used to protect most nobly all the boundaries of the realm with the shielding power of his kingship. He was the first after whom kings were called Skioldunger in the poetry of the Icelanders).

92 On Saxo, see Alistair Campbell, 'Saxo Grammaticus and Scandinavian Historical Tradition', Saga-Book, xiii (1946-1953), 1-22; Szacherska, 'Mistrz Wincenty a Saxo Gramatyk', passim; Inge Skovgaard-Petersen, 'Saxo, historian of the Patria', Mediaeval Scandinavia, ii (1969), 54-77; eadem, 'Saxo's History of the Danes: An Interpretation', Scandinavian Journal of History, xiii, 2/3 (1988), 87-93; Lars B. Mortensen, 'Saxo Grammaticus' View of the Origin of the Danes and his Historiographical Models', Cahiers de l'institut du moyen-âge grec et latin, lv (1987), 169-83; Karsten Friis-Jensen, 'Was Saxo a Canon of Lund?', Cahiers de l'institut du moyen-âge grec et latin, lix (1989), 331-57; eadem, 'Saxo Grammaticus's Study of the Roman Historiographers and his Vision of History', in Carlo Santini (ed.), Saxo Grammaticus. Tra storiografia e letteratura (Roma, 1992), 61-81.

93 Saxonis Gesta Danorum, ed. Jørgen Olrik and Hans Raeder (Haunia, 1931), 'Prologus', 1: 4, p. 5. On Saxo's Icelandic sources, see Gerd Wolfgang Weber, 'Intellegere historiam. Typological Perspectives of Nordic Prehistory - in Snorri, Saxo, Widukind and others', in Kirsten Hastrup and Preben Meulengracht-Sørensen 
In sum, the conviction that Theodoricus derived his knowledge of Platonic concepts from both the Timaeus of Calcidius - a direct source - and the commentaries of William of Conches seems justified. The latter is the most likely source of the idea of fifteen-thousand-year intervals, which Theodoricus, like William, associates with astronomical phenomena as well as natural events. Theodoricus's interest in the latter concerned only their status as natural phenomena recurring at regular intervals and resulting from comprehensible causes (interplay of the elements). In Plato, on the other hand - a source he openly cites - those events are explicitly named as the reason why Athenians were oblivious of their own history. Though the Norwegian chronicler seems to have presented the information out of its broader narrative context, that context did leave a mark on his work in the idea of a foreign memory of ancient deeds persisting through centuries - praecipua memoria vetustatis - borrowed from Timaeus. This idea was transported from Egyptian priests onto Icelandic poets "among whom in particular the remembrance of these matters is believed to thrive". The fact that the memory involved here is 'foreign' in a way discredits its rightful owners, ignorant of their own past.

These observations are, I think, vital for the study of Polish medieval historical writing. The similarities between the chronicles of Theodoricus and Master Vincentius Kadłubek are not incidental, but rather result from the use of the same sources, if not from a shared intellectual formation. They also illustrate the use to which the heritage of Antiquity was put in the lands of a 'younger Europe', ${ }^{94}$ as a resource for the constitution of individual historiographic traditions.

trans. Antoni Górny

(eds.), Tradition og historieskrivning. Kilderne til Nordens aeldste historie (Acta Jutlandica, 63, 2, Humanistisk Serie, 61, Aarhus 1987), 95 ff.; Bjarni Guðnason, 'The Icelandic Sources of Saxo Grammaticus', in Karsten Friis-Jensen (ed.) Saxo Grammaticus. A Medieval Author between Norse and Latin Culture (København, 1981), 79-93.

${ }^{94}$ Jerzy Kłoczowski, Młodsza Europa. Europa Środkowo-Wschodnia w kręgu cywilizacji chrześcijańskiej średniowiecza (Warszawa, 1998). 


\section{SELECTED BIBLIOGRAPHY}

\section{Primary Sources}

Biblia Sacra juxta Vulgatam Clementinam. Editio electronica, ed. Michaele Tvvedale (London, 2005).

Guillelmi de Conchis Glosae super Platonem, ed. Édouard Jeauneau (Corpus Christianorum, Continuatio Mediaevalis, 203, Turnhout, 2006).

Magistri Vincentii dicti Kadtubek Chronica Polonorum, ed. Marian Plezia (Monumenta Poloniae Historica, n.s., 11, Kraków, 1994).

Theodrici Monachi Historia de antiquitate regum Norwagiensium, ed. Gustav Storm (Monumenta Historica Norvegiæ. Latinske kildeskrifter til Norges historie i middelalderen udgivne efter offentlig foranstaltning, Kristiania, 1880).

Timaeus a Calcidio translatus commentarioque instructus, ed. Jan H. Waszink (London and Leiden, 1975).

\section{Secondary Sources}

Bagge Sverre, 'Theodoricus Monachus: Clerical Historiography in Twelfth-Century Norway', Scandinavian Journal of History, xiv, 2 (1989), 113-33.

Bagge Sverre, 'Theodoricus Monachus: The Kingdom of Norway and the History of Salvation', in Ildar H. Garipzanov (ed.), Historical Narratives and Christian Identity on a European Periphery (Leiden and Boston, 2011), 71-90.

Banaszkiewicz Jacek, 'Master Vincent and His Way to Revive and Present the Oldest History of the Lechites-Poles', forthcoming.

Banaszkiewicz Jacek, Polskie dzieje bajeczne Mistrza Wincentego Kadtubka (Wrocław, 2002).

Brisson Luc, Plato the Myth Maker, trans. Gerard Naddaf (Chicago and London, 1998).

Frank Tenney, 'Some Classical Quotations from the Middle Ages', Classical Philology, iv, 1 (1909), 82-3.

Johnsen Arne O., Om Theodoricus og hans "Historia de antiquitate regum Norwagiensium" (Oslo, 1939).

Kałuża Zenon, Lektury filozoficzne Wincentego Kadtubka. Zbiór studiów (Warszawa, 2014).

Lange Gudrun, Die Anfänge der isländisch-norwegischen Geschichtsschreibung (Reykjavík, 1989).

Lincoln Bruce, Between History and Myth: Stories of Harald Fairhair and the Founding of the State (Chicago and London, 2014).

Mańkowski Jerzy, 'Krak, uczeń Sokratesa (Glosa do Kadłubka Chronica Polonorum I 5, 3)', in Alina Nowicka-Jeżowa and Paweł Stępień (eds.), Inspiracje platońskie literatury staropolskiej. Materiaty z konferencji zorganizowanej przez Zespót Badań Literackich nad Historia Kultury Epok Dawnych Instytutu Literatury Polskiej Uniwersytetu Warszawskiego 14-15 października 1998 r. (Warszawa, 2000), 147-50.

Morgan Kathleen A., 'Designer History: Plato's Atlantis Story and Fourth-Century Ideology', The Journal of Hellenic Studies, cxviii (1998), 101-18. 
Paasche Fredrik, 'Über Rom und das Nachleben der Antike im norwegischen und isländischen Schrifttum des Hochmittelalters', Symbolae Osloenses, xiii (1934), 114-45.

Plezia Marian, Scripta minora. Łacina średniowieczna i Wincenty Kadtubek (Kraków, 2001).

Pomian Krzysztof, Przesztość jako przedmiot wiary. Historia $i$ filozofia $w$ myśli średniowiecza (Warszawa, 2009).

Voegelin Eric, 'Plato's Egyptian Myth', The Journal of Politics, ix, 3 (1947), 307-24. Wojtowicz Witold, 'Ateny i pamięć. Kilka uwag o założeniach ideowych "Kroniki" Mistrza Wincentego', in Łukasz Grützmacher (ed.), Narracja - historia - fikcja. Dawne kultury $w$ historiografii $i$ w literaturze (Warszawa, 2009), 87-99.

Wojtowicz Witold, 'Memoria i uczta. Kilka uwag o założeniach ideowych kroniki Mistrza Wincentego', in Andrzej Dąbrówka and Witold Wojtowicz (eds.), Onus Athlanteum. Studia nad Kronika biskupa Wincentego (Warszawa, 2009), 337-47.

Żmudzki Paweł, 'De huius rei publice origine - The Making of a Medieval Nation', forthcoming.

Rafal Rutkowski - medieval history; PhD candidate at the Institute of History, Polish Academy of Sciences; e-mail: rr.rutkowski@wp.pl 